\title{
FAKTOR YANG MEMPENGARUHI PARTISIPASI PRIA DALAM PENGGUNAAN METODE KONTRASEPSI VASEKTOMI DI KECAMATAN PAYANGAN KABUPATEN GIANYAR
}

\author{
Pande Putri Dwintasari, Ketut Hari Mulyawan* \\ Program Studi Kesehatan Masyarakat Fak. Kedokteran Universitas Udayana \\ *Email: hari.mulyawan@unud.ac.id
}

\begin{abstract}
ABSTRAK
Metode kontrasepsi vasektomi merupakan metode kontrasepsi yang memiliki efektifitas cukup tinggi dan minim efek samping. Penelitian ini bertujuan untuk mengetahui faktor yang mempengaruhi partisipasi pria dalam penggunaan metode kontrasepsi vasektomi di Kecamatan Payangan Kabupaten Gianyar. Desain penelitian menggunakan studi observasional analitik dengan desain case control. Teknik pengambilan sampel yang digunakan adalah purposive sampling dengan jumlah sampel keseluruhan 92 orang dimana masing-masing sampel kasus dan kontrol berjumlah 46 orang. Analisis bivariat menggunakan regresi logistik dengan $\alpha=0,05$. Hasil penelitian ini menggambarkan dari 92 responden, proporsi pria dari kelompok kasus 26,09\% berpendidikan tinggi, 65,22\% berpengetahuan baik, 56,52\% menyatakan jarak pelayanan kesehatan dekat, 76,09\% memperoleh dukungan baik dari petugas kesehatan dan 73,91\% memperoleh dukungan baik dari istri. Sedangkan dari kelompok kontrol, 34,78\% berpendidikan tinggi, 19,57\% berpengetahuan baik, 43,48\% menyatakan jarak pelayanan kesehatan dekat, 32,61\% memperoleh dukungan baik dari petugas kesehatan dan orang $28,26 \%$ memperoleh dukungan baik dari istri. Hasil penelitian menunjukkan terdapat tiga faktor yang memiliki hubungan yang bermakna dengan penggunaan metode kontrasepsi vasektomi yaitu tingkat pengetahuan $(p<0,001)$, dukungan petugas kesehatan $(p<0,001)$ serta dukungan istri $(p<0,001)$.
\end{abstract}

Kata Kunci: Vasektomi, Partisipasi, Pria.

\begin{abstract}
ABSTRAK
Vasectomy has high effectiveness as contraceptive method with minimum side effects. This study aims to identify factors that influence male participation on the use of vasectomy as contraceptive method in Payangan subdistrict, Gianyar regency. Study design was observational analytic with case control design. Sampling technique was purposive sampling with total sample of 92 peoples, with 46 peoples each for both cases and controls groups. Bivarate analysis was using logistic regression with $\alpha=0.05$. The result showed that of the 92 samples, $26.9 \%$, of male cases have high education, $65.22 \%$, has good awareness, $56.52 \%$ admitted that health services are in close distance, and $73.91 \%$ has good supports from their wife. Meanwhile, among the control groups, $34.78 \%$ has high education, $19.57 \%$ has good awareness, $43.48 \%$ admitted that health services are in close distance, and $32.61 \%$ has good supports from health providers and $28.6 \%$ has good supports from their wife. The result showed three factors that have significant association with the selection of vasectomy as contraceptive method are level of awareness $(p<0,001)$, support from health provide $(p<0,001)$ and support from wife $(p<0,001)$.
\end{abstract}

Keywords: Vasectomy, Participation, Male. 


\section{PENDAHULUAN}

Dalam kurun waktu 40 tahun terakhir jumlah penduduk Indonesia naik hingga dua kali lipat dari 118 juta jiwa pada tahun 1971 menjadi 237 juta jiwa pada tahun 2010. Sedangkan LPP Indonesia mengalami peningkatan dari 1,44\% pada tahun 2000 menjadi 1,49\% pada tahun 2010 (BKKBN, 2013).

Salah satu upaya yang dibuat oleh lembaga pemerintah Indonesia untuk menekan LPP disebut Program KB. Sasaran program KB adalah wanita dan pria. Salah satu metode kontrasepsi untuk pria yaitu Medis Operatif Pria (MOP) atau lebih dikenal dengan vasektomi (BKKBN, 2013).

Vasektomi adalah salah satu wujud partisipasi pria dalam program KB. Namun sampai saat ini, partisipasi pria dalam program KB masih kurang. Hal ini dapat dilihat dengan rendahnya capaian vasektomi dibandingkan dengan metode kontrasepsi lainnya.

Di Indonesia, capaian untuk vasektomi adalah sejumlah 21.374 jiwa atau hanya $0,25 \%$ dari total seluruh penggunaan metode kontrasepsi. Di Bali, capaian peserta KB aktif vasektomi sampai tahun 2015 adalah 3.959 akseptor. Kabupaten Gianyar merupakan wilayah di Provinsi Bali yang memiliki akseptor vasektomi terbanyak yaitu sejumlah 324 akseptor. Salah satu wilayah Kabupaten Gianyar yang memiliki capaian akseptor vasektomi terbanyak yaitu Kecamatan Payangan yaitu sejumlah 181 akseptor sampai tahun 2015.

Terkait dengan upaya yang telah dilakukan oleh Badan PP dan KB Kabupaten
Gianyar, peniliti ingin melihat faktor yang mempengaruhi partisipasi pria dalam penggunaan metode kontrasepsi vasektomi di Kecamatan Payangan, Kabupaten Gianyar.

\section{METODE PENELITIAN}

Penelitian menggunakan rancangan studi observasional analitik dengan desain case control dimana sampel kasus adalah Pasangan Usia Subur (PUS) yang sudah melakukan vasektomi dan sampel kontrol adalah PUS yang belum melakukan vasektomi dan memenuhi kriteria untuk menjadi sampel penelitian. Teknik pengambilan sampel yang digunakan adalah purposive sampling dengan jumlah sampel 92 orang dimana masing-masing sampel kasus dan kontrol berjumlah 46 orang yang diambil dari 7 desa yang ada di Kecamatan Payangan. Analisis bivariat menggunakan regresi logistik dengan $\alpha=0,05$.

\section{HASIL}

Karakteristik Responden Penelitian

Berdasarkan Tabel 1 dapat dilihat bahwa responden pada kelompok kasus sebagian besar berumur $\geq 45$ tahun yaitu sebesar $73,91 \%$ dan kelompok kontrol responden yang berumur $\geq 45$ tahun hanya sebesar 39,69\%. Untuk karakteristik umur istri, responden pada kelompok kasus sebagian besar memiliki istri yang berumur $\geq 42$ tahun yaitu sebesar 63,04\% sedangkan pada kelompok kontrol, istri responden yang berumur $\geq 42$ tahun hanya sebesar $36,96 \%$. 
Tabel 1. Karakteristik Responden

\begin{tabular}{|c|c|c|}
\hline Karakteristik & $\begin{array}{c}\text { Kasus } \\
\mathrm{f}(\%)\end{array}$ & $\begin{array}{c}\text { Kontrol } \\
\mathrm{f}(\%)\end{array}$ \\
\hline \multicolumn{3}{|l|}{ Umur Responden } \\
\hline$<45$ tahun & $12(26,09)$ & $29(63,04)$ \\
\hline$\geq 45$ tahun & $34(73,91)$ & $17(39,69)$ \\
\hline \multicolumn{3}{|l|}{ Umur Istri } \\
\hline$\leq 42$ tahun & $17(39,69)$ & $29(63,04)$ \\
\hline$>42$ tahun & $29(63,04)$ & $17(39,69)$ \\
\hline \multicolumn{3}{|l|}{ Pendidikan } \\
\hline Tidak bersekolah & $5(10,87)$ & $4(8,70)$ \\
\hline Tamat SD & $16(34,78)$ & $21(45,65)$ \\
\hline Tamat SMP & $13(28,26)$ & $5(10,87)$ \\
\hline Tamat SMA & $9(19,57)$ & $15(32,61)$ \\
\hline D3/PT & $3(6,52)$ & $1(2,17)$ \\
\hline \multicolumn{3}{|l|}{ Pekerjaan } \\
\hline Petani & $12(26,09)$ & $16(34,78)$ \\
\hline Buruh & $15(32,61)$ & $4(8,70)$ \\
\hline Pegawai/PNS & $4(8,70)$ & $1(2,14)$ \\
\hline Wiraswasta & $5(10,87)$ & $10(21,74)$ \\
\hline Tukang Ukir & $10(21,74)$ & $15((36,61)$ \\
\hline
\end{tabular}

Dilihat dari karakteristik pendidikan, responden pada kelompok kasus maupun kontrol sebagian besar menyelesaikan pendidikan hingga tingkat Sekolah Dasar dengan persentase masing-masing 34,78\% untuk kelompok kasus dan 45,65\% untuk kelompok kontrol. Untuk karakteristik pekerjaan, responden pada kelompok kasus paling banyak bekerja sebagai buruh yaitu sebesar 32,61\% sedangkan pada kelompok kontrol responden paling banyak bekerja sebagai petani yaitu sebesar $34,78 \%$.

Gambaran Distribusi Frekuensi Faktor Predisposisi, Pendukung, dan Pendorong 
Tabel 2. Gambaran Distribusi Frekuensi Faktor Predisposisi, Pendukung, dan Pendorong

\begin{tabular}{lcccr}
\hline \multicolumn{1}{c}{ Variabel } & \multicolumn{2}{c}{ Kasus } & \multicolumn{2}{c}{ Kontrol } \\
& $\mathrm{f}$ & $(\%)$ & $\mathrm{F}$ & $(\%)$ \\
\hline $\begin{array}{l}\text { Tingkat Pendidikan } \\
\quad \text { Rendah }\end{array}$ & 34 & 73,91 & 30 & 65,22 \\
$\quad$ Tinggi & 12 & 26,09 & 16 & 34,78 \\
Tingkat Pengetahuan & & & & \\
$\quad$ Kurang & 16 & 34,78 & 37 & 80,43 \\
$\quad$ Baik & 30 & 65,22 & 9 & 19,57 \\
Jarak ke Faskes & & & & \\
$\quad$ Jauh & 20 & 43,48 & 26 & 56,52 \\
$\quad$ Dekat & 26 & 56,52 & 20 & 43,48 \\
Dukungan Petugas Kesehatan & & & & \\
$\quad$ Kurang & & & & \\
$\quad$ Baik & 11 & 23,91 & 31 & 67,39 \\
& 35 & 67,39 & 15 & 32,61 \\
Dukungan Istri & & & & \\
$\quad$ Kurang \\
Baik
\end{tabular}

Variabel tingkat pendidikan dalam penelitian ini, responden dibagi menjadi dua kategori yaitu kategori rendah dan kategori tinggi. Berdasarkan hasil dari analisis data diketahui bahwa responden dari kelompok kasus maupun kontrol memiliki tingkat pendidikan yang rendah dengan persentase masing-masing $73,91 \%$ untuk kelompok kasus dan 65,22\% untuk kelompok kontrol.

Dilihat variabel tingkat pengetahuan, responden dibagi menjadi dua kategori yaitu kategori kurang dan kategori baik. Hasil dari analisis tingkat pengetahuan diperoleh data responden pada kelompok kasus sebagian memiliki tingkat pengetahuan baik yaitu sebesar 65,22\% sedangkan pada kelompok kontrol responden memiliki tingkat pengetahuan baik yaitu sebesar 19,57\%.

Untuk variabel keterjangkauan jarak ke fasilitas pelayanan kesehatan, hasil analisis dibagi menjadi dua kategori yaitu kategori dekat dan kategori jauh. Sebagian besar responden dari kelompok kasus menyatakan jarak ke fasilitas kesehatan dekat sebesar 56,52\% dan pada kelompok kontrol responden yang menyatakan jarak ke fasilitas pelayanan kesehatan dekat adalah sebesar $43,48 \%$.

Dilihat dari variabel dukungan petugas kesehatan kepada responden, hasil analisis dibagi menjadi dua kelompok yaitu dukungan baik dan kurang. Pada kelompok kasus sebagian besar responden menyatakan mendapat dukungan baik dari petugas 
sebesar $67,39 \%$ sedangkan pada kelompok kontrol yang mendapat dukungan baik dari petugas hanya sebesar $32,61 \%$.

Selain dukungan petugas kesehatan, dilihat juga dukungan keluarga khususnya istri terhadap penggunaan metode kontrasepsi vasektomi. Pada kelompok kasus sebagian besar responden menyatakan mendapat dukungan yang baik dari istri sebesar 73,91\% dan pada kelompok control Dalam Tabel 3 dibawah ini, diketahui bahwa hasil analisis hubungan tingkat pendidikan dengan perilaku vasektomi yaitu diperoleh $\mathrm{OR}=0,66$. yang mendapat dukungan baik dari istri hanya sebesar $28,26 \%$.

Hal ini menunjukkan bahwa orang dengan pendidikan tinggi memiliki peluang sebesar 0,66 kali untuk melakukan vasektomi dibandingkan dengan orang dengan pendidikan rendah. Namun, hasil ini tidak bermakna jika dilihat secara statistik (p-value 0,366 ).

\section{Gambaran Faktor yang Mempengaruhi Vasektomi}

Hasil analisis hubungan tingkat pengetahuan dengan perilaku vasektomi. diperoleh nilai $\mathrm{OR}=7,70$ (tabel 3). Hal ini menunjukkan bahwa orang dengan tingkat pengetahuan baik berpeluang sebesar 7,70 kali untuk melakukan vasektomi dibandingkan orang dengan orang dengan tingkat pengetahuan kurang.

Tabel 3. Faktor yang Mempengaruhi Vasektomi

\begin{tabular}{|c|c|c|c|c|c|}
\hline \multirow[t]{2}{*}{ Variabel } & \multicolumn{2}{|c|}{ Responden } & \multirow[t]{2}{*}{ OR } & \multirow[t]{2}{*}{$95 \% \mathrm{CI}$} & \multirow[t]{2}{*}{ Nilai $p$} \\
\hline & $\begin{array}{l}\text { Kasus } \\
\text { f (\%) }\end{array}$ & $\begin{array}{c}\text { Kontrol } \\
\text { f ( } \%)\end{array}$ & & & \\
\hline \multicolumn{6}{|c|}{ Tingkat Pendidikan } \\
\hline Rendah & $34(53,13)$ & $30(46,88)$ & ref & - & - \\
\hline Tinggi & $12(42,86)$ & $16(57,14)$ & 0,66 & $0,27-1,61$ & 0,366 \\
\hline \multicolumn{6}{|c|}{ Tingkat Pengetahuan } \\
\hline Kurang & $16(30,19)$ & $37(69,81)$ & ref & - & - \\
\hline Baik & $30(76,92)$ & $9(23,08)$ & 7,70 & $2,98-19,89$ & 0,001 \\
\hline \multicolumn{6}{|c|}{ Keterjangkauan Jarak } \\
\hline Jauh & $20(43,48)$ & $26(56,52)$ & ref & - & - \\
\hline Dekat & $26(56,52)$ & $20(43,48)$ & 0,59 & $0,25-1,34$ & 0,212 \\
\hline \multicolumn{6}{|l|}{ Dukungan } \\
\hline Petugas & $11(26,19)$ & $31(73,81)$ & ref & - & - \\
\hline Kurang & $35(70,00)$ & $15(30,00)$ & 6,58 & $2,63-16,43$ & $<0,001$ \\
\hline Baik & & & & & \\
\hline \multicolumn{6}{|l|}{ Dukungan Istri } \\
\hline Kurang & $12(26,67)$ & $33(73,33)$ & ref & - & - \\
\hline Baik & $34(72,34)$ & $13(27,66)$ & 7,19 & $2,86-18,03$ & $<0,001$ \\
\hline
\end{tabular}


Hasil ini juga bermakna jika dilihat secara statistik ( $p$-value $<0,001$ ). Berdasarkan hasil analisis hubungan keterjangkauan jarak dengan perilaku vasektomi diperoleh nilai $\mathrm{OR}=0,59$. Hal ini menunjukkan bahwa responden dengan jarak fasilitas pelayanan lebih dekat memiliki berpeluang sebesar 0,59 kali untuk melakukan vasektomi dibandingkan dengan responden dengan jarak fasilitas pelayanan kesehatan yang jauh. Namun, hasil ini tidak bermakna jika dilihat secara statistik ( $p$ value 0,212 ).

Hasil analisis hubungan dukungan petugas kesehatan dengan perilaku vasektomi berdasarkan hasil uji statistik diperoleh nilai $\mathrm{OR}=6,58$. Hal ini menunjukkan responden yang mendapat dukungan baik dari petugas berpeluang 6,58 kali lebih besar untuk melakukan vasektomi dibandingkan dengan responden yang kurang mendapatkan dukungan dari petugas. Hasil ini juga bermakna jika dilihat secara statistik ( $p$ value $<0,001$ )

Selain dukungan petugas kesehatan dilihat pula analisis hubungan dukungan istri dengan perilaku vasektomi, Hasil dari uji statistik diperoleh $\mathrm{OR}=7,19$. Hal ini menunjukkan bahwa responden yang mendapat dukungan baik dari istri berpeluang 7,19 kali lebih besar untuk melakukan vasektomi dibandingkan dengan responden yang kurang mendapatkan dukungan dari istri. Hasil ini juga bermakna jika dilihat secara statistik ( $p$ value $<0,001$ )

\section{DISKUSI}

Pendidikan adalah upaya yang direncanakan untuk mempengaruhi orang lain baik individu, kelompok atau masyarakat sehingga mereka melakukan

apa yang diharapkan oleh pelaku pendidikan. Berdasarkan uji statistik diperoleh nilai p-value 0,366 artinya tidak ada hubungan yang bermakna antara tingkat pendidikan dengan perilaku vasektomi. Penelitian ini sejalan dengan penelitian Ratno dkk di Kabupaten Pasaman Barat tahun 2010 yang menunjukkan tidak adanya pengaruh tingkat pendidikan terhadap pemilihan metode kontrasepsi vasektomi.

Pengetahuan adalah hasil penginderaan manusia atau hasil tahu seseorang terhadap objek melalui indra yang dimilikinya. Pengetahuan seseorang terhadap objek mempunyai intensitas atau tingkat yang berbeda-beda (Notoatmodjo, 2014). Pada penelitian ini diperoleh p-value 0,002 artinya ada hubungan yang bermakna antara tingkat pengetahuan dengan perilaku vasektomi. Kurang berperannya suami dalam program Keluarga Berencana dan Kesehatan Reproduksi disebabkan oleh pengetahuan suami mengenai $\mathrm{KB}$ secara umum relatif rendah, sebagaimana terungkap pada penelitian Suherni, dkk (1999) bahwa pria yang mengetahui secara lengkap tentang alat kontrasepsi hanya $6.2 \%$. Sebagai langkah untuk meningkatkan pengetahuan masyarakat, diantaranya petugas kesehatan perlu meningkatkan sosialisasi dan KIE pada saat melakukan pelayanan kontrasepsi. Informasi yang dimiliki oleh suami dapat meningkatkan motivasi suami untuk mengikuti vasektomi (Apriyanti, 2009).

Jarak fasilitas kesehatan yang
berdekatan dengan tempat tinggal
masyarakat, memberikan peluang kepada
masyarakat untuk melakukan pemeriksaan


kesehatan lebih awal terhadap gejala sakit yang dirasakan. Pada penelitian ini, hasil analisis statistik menunjukkan nilai $\mathrm{p}$-value 0,212 yang berarti tidak ada hubungan yang bermakna antara keterjangkauan jarak terhadap fasilitas kesehatan dengan perilaku vasektomi. Hasil penelitian ini berbeda dengan penelitian yang dilakukan oleh Wiyatmi dkk (2014) di Desa Winong, Boyolali yang mendapatkan bahwa kemudahan akses meningkatkan peluang suami untuk melakukan vasektomi dan hubungan tersebut bermakna secara statistik $(\mathrm{p}=0,002)$. Hasil penelitian ini yang mendapatkan bahwa akses jarak tidak bermakna disebabkan karena masih adanya faktor lain yang lebih berpengaruh seperti pengetahuan dan dukungan untuk melakukan vasektomi.

Untuk variabel dukungan petugas kesehatan pada penelitian ini diperoleh hasil adanya hubungan yang bermakna antara dukungan petugas kesehatan terhadap perilaku vasektomi, dilihat dari $\mathrm{p}$ value $<0,001$. Dukungan yang diberikan oleh petugas kesehatan dapat membangkitkan rasa percaya diri untuk membuat keputusan. Dukungan yang diberikan antara lain berupa informasi mengenai kesehatan yang dapat meningkatkan pengetahuan. Pengetahuan yang diperoleh tersebut dapat menimbulkan motivasi dari seseorang untuk melakukan sesuatu sesuai dengan pengetahuan yang dimilikinya. Sikap dari petugas kesehatan juga akan memberikan motivasi bagi responden. Hasil penelitian ini sejalan dengan teori Lawrence Green (1980) bahwa dukungan petugas kesehatan menjadi salah satu faktor pendorong penting yang mempengaruhi tindakan seseorang dalam memeriksakan diri ke pelayanan kesehatan atau memilih sarana pelayanan kesehatan (Notoatmodjo, 2014). Penelitian ini memperlihatkan bahwa sumber informasi yang berasal dari tenaga kesehatan merupakan faktor yang penting untuk meningkatkan partisipasi pria dalam vasektomi.

Dukungan istri adalah segala bentuk dukungan yaitu berupa sikap, tindakan dan penerimaan istri terhadap suami. Dukungan istri merupakan salah satu faktor yang mempengaruhi seseorang melakukan vasektomi. Berdasarkan hasil uji statistik diperoleh nilai p-value $<0,0001$, menunjukkan bahwa ada hubungan yang bermakna antara dukungan petugas istri dengan perilaku vasektomi. Hasil penelitian ini sejalan dengan hasil penelitian Novianti dan Gustaman (2014) yang mendaptkan bahwa dukungan istri berpengaruh terhadap partisipasi pria dalam keluarga berencana. Hal ini disebabkan tindakan vasektomi merupakan tindakan operatif yang bersifat permanen, sehingga perlu mempertimbangkan keputusan melakukan vasektomi. Maka dari itu, dukungan istri untuk melakukan vasektomi menjadi faktor pendorong suami untuk melakukan vasektomi. Penelitian ini sejalan dengan teori Lawrence Green (1980) yang menyatakan bahwa dukungan keluarga menjadi salah satu faktor pendorong penting yang mempengaruhi tindakan seseorang dalam memeriksakan diri ke pelayanan kesehatan.

\section{SIMPULAN}

Adapun kesimpulan yang dapat diambil berdasarkan hasil penelitian ini adalah : 
Sebagian besar responden baik dari kelompok kasus maupun kontrol memiliki tingkat pendidikan rendah. Tidak ada hubungan yang bermakna antara tingkat pendidikan dengan partisipasi pria dalam penggunaan metode kontrasepsi vasektomi $(p=0,036 \quad O R=0,66)$. Sebagian besar responden dari kelompok kasus memiliki pengetahuan baik dan responden dari kelompok kontrol memiliki tingkat pengetahuan kurang. Ada hubungan yang bermakna antara tingkat pengetahuan dengan partisipasi pria dalam penggunaan metode kontrasepsi vasektomi ( $p=0,001$ $\mathrm{OR}=7,70)$. Sebagian besar responden dari kelompok kasus menyatakan jarak ke fasilitas kesehatan cukup dekat tapi sebaliknya dari kelompok kontrol menyatakan jarak ke fasilitas pelayanan kesehatan jauh. Tidak ada hubungan yang bermakna antara keterjangkauan jarak ke fasilitas pelayanan kesehatan dengan partisipasi pria dalam penggunaan metode kontrasepsi vasektomi $(\mathrm{p}=0,212 \mathrm{O}=0,59)$. Sebagian besar responden pada kelompok kasus menyatakan mendapat dukungan yang baik dari petugas kesehatan sedangkan pada kelompok kasus sebagian besar menyatakan kurang mendapatkan dukungan dari petugas kesehatan. Ada hubungan yang bermakna antara dukungan petugas kesehatan dengan partisipasi pria dalam penggunaan metode kontrasepsi vasektomi ( $p=<0,001 \mathrm{OR}=6,58)$. Sebagian besar responden dari kelompok kasus mendapatkan dukungan yang baik dari istri sedangkan responden dari kelompok kontrol sebagian besar kurang mendapat dukungan dari istri untuk melakukan vasektomi. Ada hubungan yang bermakna antara dukungan istri dengan partisipasi pria dalam penggunaan metode kontrasepsi vasektomi $(p=<0,001 \mathrm{OR}=7,19)$

\section{DAFTAR PUSTAKA}

Badan Pusat Statistik (BPS). (2005). Hasil Sensus Penduduk 2005. Jakarta: BPS.

BKKBN Provinsi Bali. (2015). Laporan Bidang Advokasi, Penggerakan dan Informasi. Bali : BKKBN

BKKBN Pusat. (2014). Survei Demografi dan Kesehatan Modul Pria. Jakarta : BKKBN Pusat

BPPKB Kabupaten Gianyar. (2015). Laporan Tahunan. Gianyar : BPPKB

Budisantoso, SI. (2008). “Faktor-Faktor yang Berhiningan dengan Partisipasi Pria dalam Keluarga Berencana di Kecamatan Jetis Kabupaten Bantul Tahun 2008". Tesis. Semarang: Universitas Diponegoro

Direktorat Peningkatan Partisipasi Pria. Laporan Program Keluarga Berencana dan Partisipasi Pria tahun 2009, BKKBN, Jakarta

Hartanto, dkk, editor. (2010). Keluarga Berencana dan Kontrasepsi. Jakarta: Pustaka Sinar Harapan.

Irawan, D (2013). Perilaku Suami Terhadap Alat Kontrasepsi Pria (Vasektomi) di Desa Ujung Pulo Cut Kecamatan Bakongan Timur Kabupaten Aceh Selatan tahun 2013. Sumatera Utara : Fakultas Kesehatan Masyarakat Universitas Sumatera Utara 
Listyani, E. (2012). "Hubungan Pengetahuan Suami Tentang Keluarga Berencana dengan Sikap Suami dalam Ber-KB di Desa Mrisen Juwiring Klaten". Skripsi. Surakarta:

Universitas Muhammadyah.

Nasution, M., Dien, GAN., Ramadani,M. (2012). Faktor-Faktor yang Mempengeruhi Perilaku Akseptor KB Pria di Wilayah Kerja Puskesmas Ambacang Kota Padang Tahun 2012. Repository Universitas Andalas. Sumatra Barat.

Notoatmodjo, S. (2010). Ilmu Perilaku Kesehatan. Jakarta: PT Rineka Cipta

Noviyanti, S. \& Gustaman,RA. (2014). Faktor Persepsi dan Dukungan Istri yang Berhubungan dengan Partisipasi KB Pria. Jurnal Kesehatan Komunitas Indonesia. Vol.10 (2) September 2014.
United Nations, Department of Economic and Social Affairs, Population Division, (2015). World Population Prospects: The 2015 Revision, Key Findings and Advance Tables. Working Paper No. ESA/P/WP.241

Wahyuni, S., Suryani, N., Murdani,P.(2013). Hubungan Pegetahuan dan Sikap Akseptor KB Pria tentang Vasektomi serta Dukungan Keluarga Dengan Partisipasi Pria dalam Vasektomi. Junal Magister Kedokteran Keluarga Vol.1 (1) : 80-91. 